https://helda.helsinki.fi

\title{
ILB 938, a valuable faba bean (Vicia faba L) accession
}

\section{Khazaei, $\mathrm{H}$.}

2018-10

Khazaei , H , Link , W , Street , K \& Stoddard , F L 2018 , ' ILB 938, a valuable faba bean

(Vicia faba L) accession ' , Plant Genetic Resources , vol. 16 , no. 5 , pp. 478-482 . https://doi.org/10.1017/S1479262

http://hdl.handle.net/10138/307483

https://doi.org/10.1017/S1479262118000205

unspecified

acceptedVersion

Downloaded from Helda, University of Helsinki institutional repository.

This is an electronic reprint of the original article.

This reprint may differ from the original in pagination and typographic detail.

Please cite the original version. 


\section{ILB 938, a valuable faba bean (Vicia faba L.) accession}

2 H. Khazaei ${ }^{*}$, W. Link ${ }^{2}$, K. Street ${ }^{3}$ and F. L. Stoddard ${ }^{4}$

$3 \quad{ }^{1}$ Department of Plant Sciences, University of Saskatchewan, Saskatoon, Canada

$4 \quad{ }^{2}$ Department of Crop Sciences, Georg-August-Universität, Göttingen, Germany

$5{ }^{3}$ International Center for Agricultural Research in the Dry Areas (ICARDA), Rabat, Morocco

$6 \quad{ }^{4}$ Department of Agricultural Sciences, Viikki Plant Science Centre, and Helsinki Sustainability

$7 \quad$ Science Centre, University of Helsinki, Helsinki, Finland

8

9 *Corresponding author. E-mail: hamid.khazaei@gmail.com or hamid.khazaei@usask.ca 
11 Here we review the potential of ILB 938 (IG 12132- doi:10.18730/60FD2), a unique faba bean

12 accession originating from the Andean region of Colombia and Ecuador, maintained at ICARDA

13 - International Center for Agricultural Research in the Dry Areas, with resistance to multiple

14 biotic and abiotic stresses and carrying some useful morphological markers. It has been used as a

15 donor of leaf-related drought adaptation traits and chocolate spot (Botrytis fabae) resistance

16 genes in faba bean breeding programs worldwide. From generated populations of recombinant

17 inbred lines, QTLs (quantitative traits loci) associated with these useful traits have been mapped.

18 Other markers, such as a lack of stipule-spot pigmentation and clinging pod wall, show the

19 presence of unusual changes in biochemical pathways that may have economic value in the

20 future.

21

22 Keywords: germplasm, faba bean, biotic stress, abiotic stress, mapping population 
24 Faba bean (Vicia faba L.) seeds are a generous source of plant protein, with a global average protein concentration of $29 \%$ on a dry-weight basis (Feedipedia, 2018). It is one of the main sources of affordable protein for human consumption in developing countries (consumed as dry or canned), and for livestock feed in many developed countries. The fresh pods and seeds are widely used as a vegetable crop for fresh seed production. Like other legumes, it symbiotically fixes atmospheric nitrogen, thus improving the soil fertility. As a non-host of many cereal pathogens, faba bean is ideal as a break between grain crops in the rotation (Köpke and Nemecek, 2010). It has a mixed breeding system and is cross-pollinated at frequencies of 4-84\%, with the value determined by the interaction between the plant genotype, its environment, and the population of pollinators (Bond and Poulsen, 1983). Its interaction with many species of bee (Stoddard and Bond, 1987) makes it suitable for growing in ecological focus areas (Bues et al., 2013). It is widely adapted to cool-temperate agriculture, being grown from Mediterranean climates in southern Australia and Mediterranean basin countries to sub-boreal climates in Finland and Canada. Nevertheless, faba bean cultivation is limited due to its susceptibility to several biotic and abiotic constraints globally (see Stoddard et al., 2006; Torres et al., 2006; Khan et al., 2010). Hence, genetically diverse sources of resistance genes or genes for specific adaptations such as to abiotic stress factors are required in pre-breeding programs worldwide. Some of these germplasm sources, called 'donors' may become prominent.

Faba bean is represented in germplasm collections by only the cultivated form. Both botanical and molecular data suggest that the wild ancestors of faba bean either have vanished or have not yet been discovered (Maxted, 1993; Duc et al., 2010; Kosterin, 2014; Caracuta et al., 2016), which highlights the importance of the accessible diversity within the cultivated 
46 form. The place of origin of faba bean is still unknown. A Near or Middle East centre of origin

47 has been proposed (Cubero, 1974), and the earliest identified remains of faba bean date from

4810200 BP in a cave in Israel (Caracuta et al., 2015). Radiation followed in four directions from

49 the proposed centre: Europe, along the North Africa coast to Spain, along the Nile Valley to

50 Ethiopia, and from Mesopotamia to India and China (Lawes et al., 1983). Spanish and European

51 material was taken to South America in the $16^{\text {th }}$ century (Bond, 1976). There are 43,695 faba

52 bean accessions conserved within 37 global genebanks (ex situ, FAO, 2010) as well as on-farm

53 conservation (in situ, Suso et al., 2005). ICARDA (International Center for Agricultural

54 Research in the Dry Areas) hosts the largest collection of over 9,500 accessions (21\% of global

55 collection, FAO, 2010). ICARDA maintains its faba bean germplasm in two classes, ILB

56 (International Legume Bean) accessions from different countries, and BPL (Bean Pure Line)

57 accessions that are derived through selfing from accessions drawn from the ILB collection

58 (Saxena and Varma, 1985).

\section{Accession ILB 938}

60 ILB 938 is the result of mass selection from ILB 438 based on seed size. ILB 438 was brought to

61 ICARDA from the Andean region of Ecuador and Columbia (Robertson, 1984). ICARDA's

62 registered BPL derivatives of ILB 438 and ILB 938 are BPL 710 and BPL 1179, respectively.

63 ILB 938/2 is an inbred line developed at Göttingen for use in genetics and breeding studies. The

64 corresponding "IG" number for ILB 938 in the ICARDA genebank is "IG 12132" (accession doi:

65 10.18730/60FD2, see https://www.genesys-pgr.org/10.18730/60FD2). ILB 438 is registered as

66 IG 11632 in the ICARDA genebank (accession doi: 10.18730/601TB).

\section{Morphological markers}


68 In the wild-type faba bean, the extra-floral nectary on the stipule is coloured black. The presence

69 of stipule spot pigmentation was proposed as an early morphological marker indicating wild-type

70 'coloured' flowers (tannin-containing faba bean), where there is a black spot on each wing petal

71 and dark vein markings on the standard petal (Picard, 1976). The absence of the pigmentation

72 was considered as the corresponding early morphological indicator for the white-flower, zero-

73 tannin trait (Link et al., 2008). ILB 938, however, carries a rare allele (sspl) that decouples

74 pigmentation in flowers from that in stipules, so it has colourless stipules and coloured flowers

75 (Supplementary Figure S1, Khazaei et al., 2014a). An Australian line, AF11212, has the same

76 phenotype and is derived from BPL 710 (Dr. Jeff Paull, The University of Adelaide, Australia;

77 personal communication). Crossing ILB 938/2 with AF11212 (including reciprocal crosses)

78 showed in the F1 and F2 generations uniformly the combination of colourless stipule spots and

79 spotted flowers, confirming that the same gene exists in both accessions (Miller, 2016).

80

81

82

83

84

The seed size of ILB 938 is classified as equina (horse bean, field bean, flattened seed;

$0.6 \mathrm{~g} / \mathrm{seed}$ ) which is expected since it was the medium to large-seeded Mediterranean-adapted faba bean forms that were introduced to Central and South America by immigrants from Spain (Muratova, 1931; Cubero, 1974). The seed coat of ILB 938 is green in colour, which is recessive to the common beige or buff colour (Khazaei et al., 2014b).

A further noticeable morphological character of ILB 938 is the clinging pod wall, where fibres from the inner epidermis of the pod cling to the surface of the seed (Supplementary Figure S2). We have not seen this trait otherwise reported in faba bean germplasm, and while it is of little importance agronomically or economically, it may indicate a difference in cell wall development that has other impacts elsewhere in the plant or in the value chain. 
Finally, the funiculus is yellow in ILB 938, in contrast to the common green displayed by

91 other accessions.

92

93

94

95

96

97

98

99

100

101

102

103

104

105

106

107

108

109

\section{Biotic stresses}

The resistance of ILB 938 to chocolate spot (CS, caused by Botrytis fabae Speg.) has been demonstrated in Egypt (Mohamed et al., 1981 [re-coded NEB 938]; Khalil and Nassib, 1984;

Robertson, 1984), Syria (Hanounik, 1982), the United Kingdom (Jellis et al., 1982), Canada

(Robertson, 1984), France (Tivoli et al., 1988), and Ethiopia (Beyene et al., 2016). Further, we have noticed its resistance to CS in field conditions of both southern Finland and western Canada.

The resistance of the original source of ILB 938 was confirmed in the Nile Delta after crosses with the local cultivar Giza 3 (ICARDA Caravan, 1998; Zeid et al., 2009). From there it was transferred to locally adapted material that was released as Giza 461 in Egypt (Bond et al., 1994; Dwivedi et al., 2006; El-Komy et al., 2015).

The related bean pure lines BPL 710 and BPL 1179 to ILB 438 and ILB 938, respectively also showed high resistance to CS across environments (Hanounik and Maliha, 1986; Hanounik and Robertson, 1988; Villegas-Fernández et al., 2012). The Australian cultivar Icarus was derived from BPL 710 and released as a cultivar resistant to CS and rust (Dwivedi et al., 2006). 
110 registered as rust-resistant accessions in Australia (Ijaz et al., 2018) as well as in ICARDA 111 (1987)

Some studies have suggested that ILB 938 may also carry resistance to crenate

113 broomrape, Orobanche crenata Forsk., an achlorophyllous, holoparasitic weed, poses a major

114 constraint to faba bean production in Mediterranean climates (Zeid et al., 2006; 2009).

\section{Abiotic stresses}

116 Drought adaptation is an essential character for faba bean cultivation in arid and semiarid

117 regions. ILB 938 has demonstrated high water use efficiency (WUE) in several studies (e.g.,

118 Abdelmula et al., 1999; Link et al., 1999; Stoddard et al., 2006; Khan et al., 2007, 2010; Khazaei

119 et al., 2013; Khazaei et al., 2014b) mainly due to low stomatal conductance, thus minimizing

120 water loss and maintaining yield under drought conditions. Nevertheless, its reduced leaf

121 stomatal conductance was not associated with a highly ramified rooting system (Belachew et al.,

122 2018).

While ILB 938 has relatively low productivity, no yield penalty was observed when it

124 was exposed to drought conditions (Link et al., 1999; Khan et al., 2007; Khazaei et al., 2014b).

125 It maintains a relatively high water status under water deficit conditions, demonstrating high

126 WUE with relatively low yield, because its stomata shut early, reducing potential photosynthesis

127 while limiting water loss.

The response of ILB 938/2 to ultraviolet light differs greatly from that of a contrasting

129 cultivar, Aurora/2 that was developed at low altitudes and high latitudes where incident UV is 130 much weaker than high in the Andes (Yan et al., 2018). 


\section{Mapping populations}

132 A population of recombinant inbred lines (RILs) was developed from the cross of Mélodie/2 $\times$

133

134

135

136

137

138

139

140

141

142

143

144

145

146

147

148

149

150

151

152

ILB 938/2 (along with its reciprocal) at the University of Helsinki (Khazaei et al., 2014a). This population has been mapped for traits related to drought adaptation (Khazaei et al., 2014b), vicine-convicine concentration (v-c, Khazaei et al., 2015), and stipule spot pigmentation (Khazaei et al., 2014a). QTLs (quantitative traits loci) for seed size, seed coat colour, clinging pod wall and yellow funiculus have also been located. ILB 938 and Mélodie differed at two loci affecting stomatal activity at opposite ends of Chromosome II, with each parent contributing a canopy-cooling allele (Khazaei et al., 2014b). The progenies of this population facilitated the development of a reliable molecular marker for v-c in this crop (Khazaei et al., 2017). This population is being phenotyped for salinity response in a collaboration with Egypt and collaborative studies on other traits are in progress. Near-isogenic lines have been derived from heterozygous F5 individuals at Göttingen (Tacke and Link, 2017).

Another RIL population, ILB 938/2 × Disco/2 (Khazaei et al., 2014a), is suitable for CS genetic studies. Disco (low in both tannin and v-c) has been shown to be very sensitive to CS (Villegas-Fernández et al., 2012; Khazaei, Personal observation). A RIL population from ILB 938/2 $\times$ Aurora/2 (Khazaei et al., 2014a) will be useful for analyzing the basis of the difference in ultraviolet response of these two lines.

A multi-parent population [(Disco/2 $\times$ ILB 938/2) $\times($ IG $114476 \times$ IG 132238)] has been prepared for use in genomic studies (Khazaei et al., 2018). This population is at F4 generation at the time of writing this paper and kept at the University of Reading, UK.

\section{DNA fingerprinting}


153 ILB 938/2 was genotyped using 875 SNP (single nucleotide polymorphism) markers developed

154 by Webb et al. (2016). The results showed a high level of homozygosity (99.6\%, Webb et al.,

155 2016). The genotyping calls on ILB 938/2 are presented in Supplementary Table S1.

\section{Conclusions}

157 The presence of unusual traits in this material is intriguing, because the crop has been grown in

158 South America for only about 500 of its 10000 years of domestication. It may be attributable to

159 several causes, including widespread genetic variation introduced by the European settlers,

160 adaptation to extremely varied environments within short distances due to altitude, frequent gene

161 exchanges by pollinators and movement of peoples, and natural selection (Bond et al., 1994), or

162 UV-induced mutation. Recently, several new accessions from Spain, Ecuador, Colombia and

163 Peru with high level of resistance to CS were identified (Maalouf et al., 2016).

\section{Acknowledgments}

165 We thank Dr. Jeff Paull (The University of Adelaide, Australia) for providing the seeds of

166 AF11212. ILB 938 (IG 12132) is also acknowledged for its generous offering. FLS dedicates this

167 paper to the memory of faba bean breeder extraordinaire Dr. David Bond (1929-2017), who was

168 a kind mentor and teacher. 


\section{References}

Abdelmula AA, Link W, von Kittlitz E and Stelling D (1999) Heterosis and inheritance of drought tolerance in faba bean, Vicia faba L. Plant Breeding 118: 458-490.

Belachew KY, Nagel KA, Fiorani F and Stoddard FL (2018) Diversity in root growth responses to moisture deficit in young faba bean (Vicia faba L.) plants. PeerJ 6: e4401.

Beyene AT, John D, Sibiya J and Fikre A (2016) Gene action determining grain yield and chocolate spot (Botrytis fabae) resistance in a faba bean. Euphytica 207: 293-304.

Bond DA (1976) Field bean: Vicia faba (Leguminosae-Papilionatae). In: Simmonds NW (ed.) Evolution of Crop Plants. Longman, London, UK. pp. 179-182.

Bond DA, Jellis GJ, Rowland GG, Le Guen J, Robertson LD, Khalil SA and Li-Juan L (1994) Present status and future strategy in breeding faba beans (Vicia faba L.) for resistance to biotic and abiotic stresses. Euphytica 73: 151-166.

Bond DA and Poulsen MH (1983) Pollination. In: Hebblethwaite PD (ed.) The Faba Bean (Vicia faba L.). Butterworths, London, UK. pp. 77-101.

Bues A, Preissel S, Reckling M, Zander P, Kuhlman T, Topp K, Watson CA, Lindström K, Stoddard FL and Murphy-Bokern D. (2013). The environmental role of protein crops in the new Common Agricultural Policy. European Parliament, Directorate General for Internal Policies, Policy Department B: Structural and Cohesion Policies, Agricultural and Rural Development IP/B/AGRI/IC/2012-067.112 pp. http://www.europarl.europa.eu/studies. ISBN 978-92-823-4521-4, doi: 10.2861/27627. 
http://www.europarl.europa.eu/RegData/etudes/etudes/join/2013/495856/IPOL-

190 AGRI_ET(2013)495856_EN.pdf

191

Caracuta V, Barzilai O, Khalaily H, Milevski I, Paz Y, Vardi J, Regev L and Boaretto E (2015) The onset of faba bean farming in the southern Levant. Scientific Reports 5: 14370.

Caracuta V, Weinstein-Evron M, Kaufman D, Yeshurun R, Silvent J and Boaretto E (2016) 14,000-year-old seeds indicate the Levantine origin of the lost progenitor of faba bean. Scientific Reports 6: 37399.

Cubero J (1974) On the evolution of Vicia faba L. Theoretical and Applied Genetics 45: 47-51.

Duc G, Bao S, Baum M, Redden B, Sadiki M, Suso MJ, Vishniakova M and Zong X (2010) Diversity, maintenance and use of Vicia faba L. genetic resources. Field Crops Research 115: 270-278.

Dwivedi SL, Blair MW, Upadhyaya HD, Serraj R, Balaji J, Buhariwalla HK, Ortiz R and Crouch JH (2006) Using genomics to exploit grain biodiversity in crop improvement. Plant Breeding Reviews 26: 171-310.

El-Komy MH, Saleh AA and Molan YY (2015) Resistance/susceptibility of faba bean to Botrytis fabae: the causal agent of chocolate spot with respect to leaf position. International Journal of Agriculture and Biology 17: 691-701.

FAO (2010) The second report on the state of the world's plant genetic resources for food and agriculture. Rome, Italy. http://www.fao.org/docrep/013/i1500e/i1500e00.htm, accessed 01May 2018. 
209 Feedipedia (2018) Faba bean (Vicia faba). https://www.feedipedia.org/node/4926, accessed 01 May 2018.

211 Hanounik SB (1982) Resistance in faba beans to chocolate spot. FABIS Newsletter 5: 24-26.

212 Hanounik SB and Maliha N (1986) Horizontal and vertical resistance in Vicia faba to chocolate 213 spot caused by Botrytis fabae. Plant Disease 70: 770-773.

214 Hanounik SB and Robertson LD (1988) New sources of resistance in Vicia faba to chocolate 215 spot caused by Botrytis fabae. Plant Disease 72: 696-698.

216 ICARDA (1987) Faba bean pathology progress report 1986-1987. In: Food Legume

217 Improvement Program, ICARDA, Aleppo, Syria.

218 ICARDA Caravan (1998) Review of agriculture in the dry areas. Issue No. 9. https://apps.icarda.org/wsInternet/wsInternet.asmx/DownloadFileToLocal?filePath=Cara van/Caravan9.pdf\&fileName=Caravan9.pdf, accessed 01 May 2018.

221 Ijaz U, Adhikari KN, Stoddard FL and Trethowan RM (2018) Rust resistance in faba bean (Vicia 222 faba L.): status and strategies for improvement. Australasian Plant Pathology 47: 71-81.

223 Jellis GJ, Bond DA and Old J (1982) Resistance to chocolate spot (Botrytis fabae) in ICARDA 224 accessions of Vicia faba. FABIS Newsletter 4: 53-54.

225 Khalil SA and Nassib AM (1984) Identification of some sources of resistance to disease in faba 226 bean. I. Chocolate spot (Botrytis fabae Sard.). FABIS Newsletter 10: 18-21. 
Khalil SA, Nassib AM and Mohammed HA (1985) Identification of some sources of resistance to diseases in faba beans II-Rust (Uromyces fabae). FABIS Newsletter 11: 18-20.

Khan HR, Link W, Hocking TJH and Stoddard FL (2007) Evaluation of physiological traits for improving drought tolerance in faba bean (Vicia faba L.). Plant and Soil 292: 205-217.

Khan HR, Paull JG, Siddique KHM and Stoddard FL (2010) Faba bean breeding for drought affected environments: A physiological and agronomic perspective. Field Crops Research 115: 279-286.

Khazaei H, O’Sullivan DM, Jones H, Pitts N, Sillanpää MJ, Pärssinen P, Manninen O and Stoddard FL (2015) Flanking SNP markers for vicine-convicine concentration in faba bean (Vicia faba L.). Molecular Breeding 35: 38.

Khazaei H, O’Sullivan DM, Sillanpää MJ and Stoddard FL (2014a) Genetic analysis reveals a novel locus in Vicia faba decoupling pigmentation in the flower from that in the extrafloral nectaries. Molecular Breeding 34: 1507-1513.

Khazaei H, O’Sullivan DM, Sillanpää MJ and Stoddard FL (2014b) Use of synteny to identify candidate genes underlying QTL controlling stomatal traits in faba bean (Vicia faba L.). Theoretical and Applied Genetics 127: 2371-2385.

Khazaei H, Purves RW, Song M, Stonehouse R, Bett KE, Stoddard FL and Vandenberg A (2017) Development and validation of a robust, breeder-friendly molecular marker for the $v c^{-}$locus in faba bean. Molecular Breeding 37: 140. 
Khazaei H, Purves RW, Stoddard FL and Vandenberg A (2018) A multi-parent faba bean (Vicia faba L.) population for future genomic studies. Plant Genetic Resources (in press).

Khazaei H, Street K, Bari A, Santanen A and Stoddard FL (2013) Do faba bean (Vicia faba L.) accessions from environments with contrasting seasonal moisture availabilities differ in stomatal characteristics and related traits? Genetic Resources and Crop Evolution 60: $2343-2357$.

Kosterin OE (2014) The lost ancestors of the broad bean (Vicia faba L.) and the origin of plant cultivation in the Near East. Vavilov Journal of Genetics and Breeding 18(4/1): 831-840.

Köpke U and Nemecek T (2010) Ecological services of faba bean. Field Crops Research 115: 217-233.

Lawes DA, Bond DA and Poulsen MH (1983) Classification, origin, breeding methods and objectives. In: Hebblethwaite PD (ed.) The Faba Bean (Vicia faba L.). Butterworths, London, UK. pp. 23-76.

Link W, Abdelmula AA, Kittlitz E von, Bruns S, Riemer H and Stelling D (1999) Genotypic variation for drought tolerance in Vicia faba. Plant Breeding 118: 477-483.

Link W, Hanafy M, Malenica N, Jacobsen H-J and Jelenić S (2008) Broad bean. In: Kole C and Hall TC (eds) A Compendium of Transgenic Crop Plants: Transgenic Legume Grains and Forages. Vol. 3. Wiley, New York, pp. 71-88. 
Maalouf F, Ahmed S, Shaaban K, Bassam B, Nawar F, Singh M and Amri A (2016) New faba bean germplasm with multiple resistances to Ascochyta blight, chocolate spot and rust diseases. Euphytica 211: 157-167.

Maxted N (1993) A phenetic investigation of Vicia L. subgenus Vicia (Leguminosae, Vicieae). Botanical Journal of the Linnean Society 111: 155-182.

Miller M (2016) Genetics of pigmentation in faba bean (Vicia faba L.). Undergraduate Thesis. University of Saskatchewan, Canada.

Mohamed HA, Zeid NA and Habib WF (1981) Variation with the fungus Botrytis fabae Sard. FABIS Newsletter 3: 49-50.

Muratova VS (1931) Common beans (Vicia faba L.). Bulletin of Applied Botany of Genetics and Plant Breeding 50: 1-298.

Picard J (1976) Aperçu sur l'héredité du caractère absence de tannins dans les graines de féverole (Vicia faba L.). Annales de l'Amélioration des Plantes 26: 101-106.

Rashid KY and Bernier CC (1986) Selection for slow rusting in faba bean (Vicia faba L.) to Uromyces viciae-fabae. Crop Protection 5: 218-224.

Rashid KY and Bernier CC (1991) The effect of rust on yield of faba bean cultivars and slow rusting populations. Canadian Journal of Plant Science 71: 967-972.

Robertson LD (1984) A Note on the I.L.B. Source of Botrytis fabae resistance. In: Chapman GP and Tarawali SA (eds) Systems for Cytogenetic Analysis in Vicia faba L. Advances in Agricultural Biotechnology. Vol 11. Springer, Dordrecht. 
284 Saxena MC and Varma S (1985) Faba beans, Kabuli chickpeas, and lentils in the 1980s. An

285

286

287

288

289

290

291

292

293

294

295

296

297

298

299

300

301

302

303

304 international workshop. May 16-20, 1983; proceedings. International Centre for Agricultural Research in the Dry Areas. Aleppo, Syria.

Stoddard FL and Bond DA (1987) The pollination requirements of the faba bean (Vicia faba L.). Bee World 68: 144-152.

Stoddard FL, Balko C, Erskine W, Khan HR, Link W and Sarker A (2006) Screening techniques and sources of resistance to abiotic stresses in cool-season food legumes. Euphytica 147: $167-186$.

Suso MJ, Moreno MT and Cubero JI (1993) Variation among Spanish faba bean cultivars: taxonomy and evolutionary implications. Genetic Resources and Crop Evolution 40: 105-111.

Tacke R and Link W (2017) Towards a localization of the " $v c$-" gene responsible for low vicine and convicine content in seeds of faba bean (Vicia faba L.) and towards a low vicine and convicine winter faba bean cultivar. In: $8^{\text {th }}$ International Conference on Legume Genetics and Genomics, September 18-22. Siófok, Hungary. p. 115.

Tivoli B, Berthelem P, Leguen J and Onfroy C (1988) A study of the performance of certain faba bean genotypes in relation to Botrytis fabae and Ascochyta fabae in France. FABIS Newsletter 21: 36-39.

Torres AM, Roman B, Avila CM, Satovic Z, Rubiales D, Sillero JC, Cubero JI and Moreno MT (2006) Faba bean breeding for resistance against biotic stresses: towards applications of marker technology. Euphytica 147: 67-80. 
Villegas-Fernández AM, Sillero JC and Rubiales D (2012) Screening faba bean for chocolate spot resistance: evaluation methods and effects of age of host tissue and temperature. European Journal of Plant Pathology 132: 443-453.

Webb A, Cottage A, Wood T, Khamassi K, Hobbs D, Gostkiewicz K, White M, Khazaei H, Ali M, Street D, Stoddard FL, Maalouf F, Ogbonnaya F, Link W, Thomas J and O'Sullivan DM (2016) A SNP-based consensus genetic map for synteny-based trait targeting in faba bean (Vicia faba L.). Plant Biotechnology Journal 14: 177-185.

Yan Y, Neugart S, Stoddard FL and Aphalo PJ (2018) Different responses to solar ultraviolet (UV) and blue radiation in two accessions of Vicia faba over two generations. Aspects of Applied Biology 138, Advances in Legume Science and Practice, pp. 63-64.

Zeid M, Ghazy AI and Link W (2006) Questing for Orobanche crenata resistance genes in faba bean. In: New Life Sciences: Changing Lives, 26-29 April 2006, BioVision Alexandria, Egypt.

Zeid M, Mitchell S, Link W, Carter M, Nawar A, Fulton T and Kresovich S (2009) Simple sequence repeats (SSRs) in faba bean: new loci from Orobanche-resistant cultivar 'Giza 402'. Plant Breeding 128: 149-155. 